\title{
Calling, is there anything special about it?
}

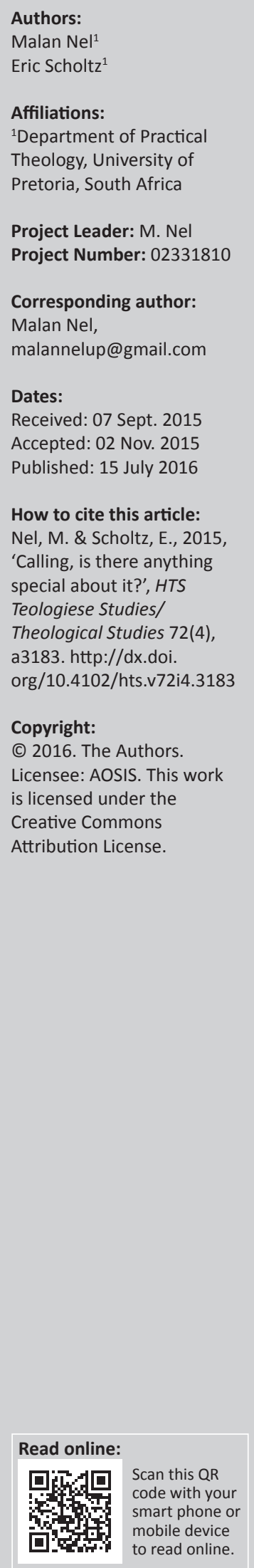

Within the Reformed tradition, 'calling' is a core concept. Often, this biblical verse is cited when a pastor is installed or a new candidate is ordained, "The one who calls you is faithful and he will do it' (1 Th 5:24 NIV). It is also confessed within this tradition that all Christians are called to be faithful ministers of the graces of God in whatever profession they may serve. In some Presbyterian congregations, it is a practice to say at the baptism of a child, "This is your ordination to ministry'. This article focuses on what is meant by calling when we use it in so many ways and with so many meanings. The first part explores the use of the concept in church history by different scholars and leaders - like in the Reformation. The second part briefly explores the implications and impact of the calling of someone into full-time congregational ministry.

\section{Introduction}

We perceive that 'calling' is being used in different contexts, meaning different things to different people. While we admit that it is a core concept in theology and ministerial practice, we ask, 'What does it mean, what is it supposed to mean and how do we rediscover its meaning when we use it in the vocabulary of Theology and ministry?' This article will explore this 'meaning,' and in the second part of the article, we will focus especially on the implications for persons in so-called full time congregational ministry.

We consider it a great privilege to participate in a Festschrift for an esteemed colleague and friend. His commitment to his field and his calling as a pastor and academic are well known and respected. It was this commitment to his calling that inspired us to explore the theme of calling in this article.

\section{'Calling': The concept and its meaning in history}

The ways Christians think about vocation have changed significantly over the centuries. There seem to be a broad consensus amongst writers who trace the development of the concept of vocation in history about the major turns regarding the meaning of the concept. Four historical periods are usually discerned, each with a distinctive contribution to the meaning of vocation. These are the early church, the Middle Ages, the Reformation period and the modern period (cf. Gerkin 1991:143-151; cf. Placher 2005:loc.153-193).

For the first several hundred years of Christianity, up to the time of Emperor Constantine, Christians were a minority group and often at risk in society (Placher 2005:loc.153). Becoming a Christian frequently meant a break from family and a previous way of life. The decision to follow Christ made the Christians outsiders to many facets of society, uncomfortable with its standard forms of entertainment and unable to share in much of its social life. In the Roman Empire, where most of the Christians lived, refusal to perform the sacrifices of the imperial cult was technically illegal. Even if the risk was usually small, not partaking in these sacrifices meant the possibility of arrest, torture and death (cf. Freeman 2009:210-211). 'Thus the fundamental vocational questions for Christians or potential Christians were initially, first, should I be a Christian? And, second, how public should I be about my Christian faith' (Placher 2005:loc.153). Within the context of the early church, vocation was accordingly understood as the call to discipleship that included the call to community.

This understanding of vocation, as the double call to discipleship and community, is in continuance with the New Testament understanding of the term. According to Fowler (1987:28), the Greek word klesis, translated as 'calling, invitation, summons', refers to the special relationship with God to which all followers of Christ are called. The word ekklesia, which literally means a 'calling out', makes the communal aspect of those who are called apparent. Ekklesia is the fellowship of those who have been called out by God into reconciled relation with one another and with God. 
The meaning of the word klesis in the New Testament is not exhausted by the above explication. Paul, for instance, introduces himself to his readers in Romans 1:1 as a kletos apostolos, as someone who has been called to be an apostle (Conyers 2004:17). Used in this sense, kletos is linked to the calling to a particular office, namely that of an apostle. In 1 Corinthians 7:20, Paul advises his readers to remain in the klesis to which he or she was called. This usage of klesis could refer to one's occupation, in which case it is the only instance in the New Testament where it has reference to work (Holl 1958:127). Hays (2011:loc.2708) gives a much broader interpretation of the term: '[B]elievers should remain in the condition in which they were called - their position in life at the time they first accepted the preaching of the good news about Christ'. Within the immediate context of 1 Corinthians 7 , 'their position in life' is related to married/unmarried, circumcised/uncircumcised and slave/free. Fowler (1987:28) acknowledges the difficulty of interpretation at this point with his remark that:

[w] cannot know for sure whether this use of klesis referred to occupation or position in the modern sense or whether it referred to a call to fidelity to the general call of all Christians in their relationship with God in Christ.

In the 4th century, after Emperor Constantine became a Christian, the situation facing Christians changed (Placher 2005:loc.153). New converts joined the church in droves. Becoming and being a Christian no longer meant taking great risks; it could even be to one's advantage and provide a convenient way to progress in society (Hardy 1990:loc.666). Hereafter, for nearly a thousand years in the Middle Ages, the vast majority of Christians grew up in the church, surrounded by other Christians. One no longer entered into Christianity by means of a personal decision; one was born and baptised into it (Holl 1958:128). The thought of a calling coming clearly to the consciousness of each individual faded completely. This brought new questions to the fore: How could Christians preserve a sense that Christianity involved a cost? What were Christians called to do when it seemed easy to be a Christian (cf. Froelich 1999:197-198)? Some Christians became priests, monks, nuns or friars and found their calling in lives of radical self-denial, through which they sought to preserve the far-reaching challenge of Christianity:

Indeed, for medieval Christians 'having a vocation' ... meant almost exclusively joining the priesthood or some monastic order. Thus the central vocational choice for Christians was should I stay a part of my family, marrying, having children; or choose the priesthood or the 'religious' life in a convent or a monastery or as a wandering friar... (Placher 2005:loc.163).

Ordinary Christians could be saved, but only monks, priests and bishops had callings (Fowler 1987:28). Only for the emperor was something similar acknowledged, that God appoints the ruler over his people (Holl 1958:131).

In the late Middle Ages, through the writings of Berthold of Regensburg and especially the German mystics, like Meister Eckhardt and Johann Tauler, we see the first real linking of secular occupations to the concept of callings (Holl 1958: 138-142). Referring to Tauler, Holl (1958:142) writes, 'Here for the first time the thought of a secular calling (Beruf) was discovered'. It should be noted, however, that the concept of vocation was still held within limits. Neither Tauler nor any of the other mystics had any thought of setting aside the superiority of monasticism over the common heap of normal Christianity (Holl 1958:143). This was the accomplishment of Luther. 'Martin Luther brought to a kind of completion the extension to secular work of the dignity of a calling' (Fowler 1987:30), although it should be noted that Luther and the Protestant Reformation not only extended to secular work the dignity of a calling but also brought about a reversal in the valuing of the monastic ideal (Dawson 2005:223).

Luther's discovery that we are saved by God's grace and not by our own works initiated a series of momentous events during the Protestant Reformation. Relevant to the current discussion, it cut through the two-tiered spirituality of the medieval world, which distinguished between the laity and the clergy, the ordinary Christian and the monk (cf. Hardy 1990:loc.654). Luther proclaimed the priesthood of all believers. Not only some but all Christians have a vocation, not only in the sense of a call to faith but also as a call to serve God and one's neighbour in a concrete way (cf. Smit 2002:485-486).

Luther did more than equalise the relationship between the laity and the clergy. In some instances, he turned it on its head:

For Luther, therefore, the private life of devotion exercised in the seclusion of the monastery, rather than being the exercise of a vocational calling, represented an effort to justify oneself before God by one's works of devotion... (Gerkin 1991:145-146).

Luther rejects the monastic life as a so-called Christian vocation (McCollough 1961:26). God does not call us out of the world but to the world (Smit 2002:485).

To follow Luther's thoughts on vocation, it is important to recall a basic theological distinction he drew between the kingdom of heaven and the kingdom of earth:

To the kingdom of heaven belongs our relationship to God, which is based upon faith; to the kingdom of earth belongs our relationship to our neighbor, which is to be based upon love (Hardy 1990:loc.595).

Vocations are located within the kingdom of earth, where we are called to love our neighbour. For this reason, the monastic life cannot be considered a Christian vocation, for in it one cultivates one's own spiritual life in separation from the neighbour (cf. Hardy 1990:loc.630-642). 'Vocation is not for the purpose of self-expression or self-fulfilment, but for the service of others' (McCollough 1961:26). The call to service goes out to all. This does not mean that the call is the same for each and every one. The particularity of the call is realised within the station in life that one currently occupies:

As conceived by Luther, our stations include all the typical ways in which we are related to other people. Being a husband or 
a wife is a station in life, as well as being a parent or a child, a magistrate or a subject, a master or a servant, as well as a baker, a cobbler, or a farmer (Hardy 1990:loc.595).

Vocation refers to all of one's relationships, situations, contexts and involvements (Kolden 1983:386). Luther's understanding of the stations in life concurs with the late medieval view in Western Europe. He accepts this view uncritically as self-evident. Smit (2002) captures the late medieval view on the stations in life as follows:

In die laat-Middeleeuse Wes-Europese samelewings, veral in die stede, wat toenemend belangrik begin word, vind mens dus dat die lewe georden word volgens ' $n$ verskeidenheid van beroepe en stande (op Latyn onderskei tussen ordo, ministerium, professio, officium). Mense het aanvaar dat hierdie soort verdelinge met die natuur gegee is, so hoort, en Godgewil is. (p. 484)

Notwithstanding some points of convergence with the medieval view, Luther brought about a major renewal in the understanding of vocation. Holl (1958) summarises the radical turn introduced by Luther's position on vocation:

The history of the word thus shows a complete reversal of its meaning. At first it meant, the monk alone has a calling (Beruf); Luther says just the reverse, it is exactly monasticism which has no calling; the genuine calling of God realizes itself within the world and its work. (p. 153)

John Calvin confirms Luther's judgement on monasticism. Calvin (1960b:1261-1262) shows some appreciation for monasticism in the early church as described by Augustine and testified to by Gregory of Nazianzus, Pseudo-Basil and Chrysostom. Calvin is, however, very critical of later monasticism and denies any meaningful association with the early monasticism. He can hardly hide his aversion for, amongst other things, later monasticism's 'rigid requirement of ... things left free to us by the Lord's word', their idleness, their boastfulness, their immoral lifestyle and their sectarianism (Calvin 1960b:1264-1272). He writes in the same vein as Luther about the importance of 'brotherly love', which he sees betrayed in the later monastic order because it became 'a conspiracy by which a few men, bound together among themselves, are separated from the whole body of the church' (Calvin 1960b:1264-1265).

Calvin is in solidarity with Luther about the religious dignity of work and the call of God that reaches us in all aspects of our lives. 'Calvinism sought to glorify the sovereign Lord in the life of this world in very practical ways' (McCollough 1961:27). In the Institutes, Calvin (1960a:724) writes, 'Finally, this point is to be noted: the Lord bids each one of us in all life's actions to look to his calling'. While Calvin is in general agreement with Luther about the meaning of vocation, he develops a personal emphasis and also adds an important amendment. According to Hardy (1990:loc.744-790), Calvin emphasises the connection between work and a person's social responsibility.

Calvin saw that Luther's thought on vocation suffered the limitation of an unqualified acceptance of the status quo, setting a divine stamp of approval on the existing structures of society (McCollough 1961:27). In his commentary on 1 Corinthians 7:20,24, the same text that Luther derived his more static view of vocations from, Calvin goes beyond defining God's calling as a way of life divinely imposed upon people. He writes, 'Ek heb boven vermaand, dat hier de menschen niet gedrongen worden door een eeuwige wet nimmermeer den stand des levens te veranderen' (Calvijn 1972:127). The Calvinists realised that the institutional shape of our earthly stations is also a product of human culture and therefore exposed to sin (Hardy 1990:loc.790-802). It should not be accepted undiscriminatingly but should be scrutinised with the critical eye of an Old Testament prophet. Hardy (1999:loc.815) finds an example of this in a sermon by Calvin on Ephesians 6:5-9, where Calvin 'proceeds to attack the whole institution of the bondservant as "totally against the order of nature"...' The Calvinist position on vocation distinguishes itself from the Lutheran in that it does not absolutise the stations in life. Vocation pertains to the use of our talents and abilities in the service of God and our neighbour via our stations.

Hahnenberg (2010:loc.508-522) describes the 'subtle shift' in Calvin's position compared with Luther's: 'Luther saw vocation as the call to serve one's neighbor within the context of one's work and life. Calvin tended to identify it more with the work itself'. This opened the door to the later identification of vocation with one's occupation:

[A]s duty to God within [italics in original] one's station became duty to God through [italics in original] one's station, it was only a short step toward seeing vocation as simply the duty to [italics in original] one's station (Hahnenberg 2010:loc.640).

This eventually happened, and in modern times it contributed to the secularisation of the concept of vocation. Whereas by the end of the 19th century vocation was narrowly defined as any sort of work, in the 20th century it became a matter of individual choice, without reference to the one who calls (cf. Gerkin 1991:147-148).

This does not mean that vocation as a subject of theological thought has been dropped from the agenda. The world we live in threatens us with meaninglessness and emptiness. 'Finding our way, the search for meaning, discovering our path, - these are the themes of a contemporary theology of vocation' (Hahnenberg 2010:loc.2339). According to Hahnenberg (2010), the work of the 20th-century theologian Karl Barth is a response to this emptiness:

Karl Barth was keenly aware of the anxiety brought on by the emptiness of modern subjectivity. In many ways, his project can be seen as a positive reply to the drift of a theology detached from its source. His writings wrench his reader's gaze away from the human subject and direct it to the 'theological object'. (loc.2353)

In his Church Dogmatics (volumes III/4 and IV/3.2), Barth discusses vocation at length. His understanding of vocation is ruled by the important distinction between Beruf and Berufung (cf. Kuzmič 2005:263-268; cf. Thrall 1976:86). 
Barth (1961:598) draws attention to this distinction: 'We must make a clear distinction, therefore, between calling in the sense of vocation and calling as the divine summons'. Calling in the sense of vocation is what Barth refers to as Beruf. A person's Beruf designates that which he 'owes to the creation and providence of God' (Barth 1961:595). 'It is he himself in his nature and being' (Barth 1961:598). '[V]ocation is the whole of the particularity, limitation and restriction ... differentiation and specification' that defines a person 'as this man and not another' (Barth 1961:599-600). Hahnenberg (2010) concludes as follows:

In other words, my vocation is not my profession; it is my person seen as a unique creation placed by God in a particular time, at a particular place, and gifted with particular abilities, disabilities, experiences, and associations. (loc.2512)

Therefore, vocation is unique to every person (Barth 1961:600). Although Barth is critical of Luther's understanding of stations in life, we see in Barth a creative use of Luther's insight that we are called by God to serve God and neighbour precisely where we are (Hahnenberg 2010:loc.2512).

Berufung is God's call, God's summons that reaches a person in his or her vocation (Beruf) (cf. Kuzmič 2005:264). Berufung is not a restating of a person's Beruf; it is not 'merely a confirmation of the special thing which man has been already on the basis of the creation and providence of God' (Barth 1961:595). Calling (Berufung) in this sense:

is the new thing which is added to what man already is before God, ... it will always mean something materially new for man, a broadening, lengthening, alteration ..., a modification of human existence which reaches out beyond its earlier form. (Barth 1961:598)

Vocation (Beruf) is to some extent 'only the framework within which he is to be free and obedient according to the command of God' (Barth 1961:597). One's vocation (Beruf) is not a fixed position but can be changed in obedience to the call (Berufung) of God (McCollough 1961:280). This, however, does not mean that God in his call is completely arbitrary. Berufung does not contradict Beruf, for ' $[t]$ he commanding God is the Creator and Lord of man even before $\mathrm{He}$ addresses him in His command' (Barth 1961:595). In every case, there will be a continuity between Beruf and Berufung. Berufung contains the essence of the old thing (Beruf) that a person already is, which the person brings with him or her as the new call comes to the person (Kuzmič 2005:264). The divine calling (Berufung) both confronts and corresponds to an individual's vocation (Beruf):

The word of God, the summons that is the divine call, is not a general invitation but a well-aimed shot that hits me where I am and prompts me to respond precisely in this context (Hahnenberg 2010:loc.2541)

In Hahnenberg's view (2010:loc.1123), the above description of the development of the concept of vocation in history represents only one line of thought. It tells the story of the broadening of the concept. Especially in Catholic theology, there is a second major story line to be considered. The caption for this second story line is the deepening of the call. What Hahnenberg has in mind is the account of the long-standing tension between the understanding of vocation as an external call and vocation as an internal call. This tension already came to the fore in the monastic period, where a distinction was drawn between the call of the priest and the call of the monk. While the priest received his vocation via an external call, the monk received his via an internal call. The call of the cleric came through the bishop or the community. The vocation of the monk came directly from God. 'It was the monk who bequeathed to the church the notion of the inner call' (Hahnenberg 2010:loc.1162). It seems as if Hahnenberg makes a further distinction with reference to this inner call. On the one hand, vocation is seen as 'an extrinsic force, a kind of secret voice whispering within' (Hahnenberg 2010:loc.1123). On the other hand, vocation is seen as the fruit of an interplay 'between personality and grace' (Hahnenberg 2010:loc.1149).

Hahnenberg (2010:loc.1218-1389) discusses Ignatius of Loyola as an outstanding representative of the last-mentioned approach, in whose work vocation underwent a further deepening. Ignatius's own life experience is the basis on which he constructed his understanding of vocation:

Ignatius came to believe that God was silently speaking to him through the inner movements of his thoughts and feelings. By attending to these thoughts and feelings, Ignatius discovered God's specific will for his life (Hahnenberg 2010:loc.1245).

Hahnenberg (2010) elucidates what this means in terms of vocation. God does not speak:

to [italics in original] our fallen nature but through [italics in original] our graced existence ... our vocation is not foreign to us, imposed by God from outside ... Our vocation is our unique, outward life of freedom that we can only recognize and embrace through the inner liberation of our affections by grace. (loc.1359)

According to Hahnenberg, the concept of vocation is rooted in our understanding of the relationship between nature and grace. For Ignatius, vocation is not an extrinsic, supernatural grace, but 'Ignatius maintained the basic integrity of nature, a nature intrinsically restored through grace' (Hahnenberg 2010:1oc.1359).

That our vocation coincides with our nature, restored through grace, is a recurrent theme in modern-day thoughts on vocation. It appears not only in Catholic but also in other theologies of vocation. The Catholic theologian Herbert Alphonso states that your 'personal identity', your 'personal orientation in life', your 'most profound and true self' is your vocation in life. According to the Quaker Parker Palmer (2000:loc.62), understanding your vocation requires you to 'let your life speak'. The Anglican Rowan Williams (2014:loc.2409) explains that God does not 'drop a vocation on you', but 'we need to think of him speaking over and over again the same [italics in original] word to us - our true name, our real identity'. In this sense of the word, vocation has more to do with being than with doing:

$[W]$ ork takes up so many of our waking hours that our jobs come to define us and give us our identities. We become what we do. Calling reverses such thinking ... Instead of, 'You are what you do', calling says: 'Do what you are'. (Os Guinness 1998:loc.526) 
The history of the word 'vocation' shows that it is a manylayered concept. It includes our calling to discipleship, the joining of the faith community; it stretches out over all aspects of life and takes hold of us in a very personal way.

\section{'Calling': implications for fulltime congregational ministry}

The previous section, on the history and meaning of the word 'vocation', ended on a very personal note, emphasising the deep, personal character of the call. Hahnenberg (2010:loc.3332), however, warns against an unbridled individualism regarding our understanding of the call. 'In constructing a contemporary theology of call, the problem is not emphasizing the individual. The problem is isolating her'. This is especially true within a postmodern context that looks with suspicion 'on the Enlightenment ideal of the detached subject, who hovers free from influence and all authority, constructing meaning from a neutral point of pure rationality' (Hahnenberg 2010:loc.3332-3345).

A postmodern perspective shows appreciation for the contextual nature of human existence. My own story is always embedded within other stories as I interact with the people, cultures, institutions and traditions that constitute the context of my life. Translated in terms of vocation, this means, 'Vocation is my story amidst other stories, as all of these stories unfold within the story of God' (Hahnenberg 2010:loc.3345). In the rest of this article, we wish to reflect on how the story of the church might impact on the understanding of vocation. In Hahnenberg's (2010:loc.3332) words, we also need an ecclesiology of vocation.

In a previous publication on this subject (cf. Nel 2002:157), it was stated that a calling to full-time congregational ministry implies that the person:

- understands the calling to be a fulfilment of her or his 'purpose of life as a creature (like all other creatures) of God'

- is 'willing for and committed to what this profession calls for - even though the requirements are comprehensive, often tiresome and risky'

- is willing for and committed to the implications of training to 'qualify' for this profession and continuing training to remain in this profession (lifelong learning)

- is committed to lifelong evaluation as part of the privilege of being and remaining in this profession.

The article suggested that a new view of the congregation as the working people of God has a serious impact on our understanding of the 'people' (pastors or whatever other name they may carry) being called to full-time ministry. They are being called from among the working people of God (in a sense as one of them), with a specific calling towards the very same people. Since 2002, this understanding of the congregation grew to a greater fullness of what it means to be a congregation in mission. Within the missional conversation (cf. Nel 2015:25-50,63-79), it is well accepted that we think of a congregation as a congregation in mission no longer just doing missions but being in mission (cf. also Bosch 1991; Van Gelder \& Zscheile 2011). This understanding changes our approach to full-time ministry quite dramatically. Gibbs (2005), Gibbs and Coffey (2001) has also reflected on these 'quantum changes in Christian ministry' and leadership.

In a sense, this implies that the calling of a pastor has to be secularised. A decade earlier, Schaller (1994) had already anticipated this:

From the perspective of the year 2018, perhaps the most far reaching bad news is the inability of today's theological seminaries to attract adequate numbers of highly competent, exceptionally gifted, deeply committed, and clearly extroverted adults born after 1965 who possess a compelling call to parish ministry ... The time has arrived for a new system for enlisting, training, screening, and credentialing the next generation of parish pastors. (p. 21)

This means, to our minds, a growing understanding that the calling of a pastor is a calling to a 'job' - however important and responsible that calling and job may be. All people are being called to a profession. As indicated already above, work or labour is a calling (cf. Dekker 1996:13-21). In the words of Weber (1920:63,203; cf. also 1991:118-122), 'Der Puritaner wollte Berufsmensch sein, - wir müssen es sein'. In the Reformed tradition, this even found expression in the Confessions (cf. (HC Sunday 49). In the words of the classical ethicist Brillenburg Wurth (1951:257-258), 'God doet in Christus op ons Zijn goddelijk beroep, God vordert in Christus ons op, om ook in onze dagelijkse bezigheden Hem te dienen'. ${ }^{1}$ According to the sociologist Wuthnow (1992:69), some $50 \%$ of all church goers in the USA feel that God has called them to the work they do (Nel 2002:153).

Most pastors in the Reformed tradition preach and teach this understanding of work. It, however, applies to the preacher too.

For a deeper understanding of the calling to full-time congregational ministry, we may need to have a more honest approach to work itself. The question then becomes what kind of work is needed to 'prepare' God's people for the ministry or work they have been called to. Within a Calvinistic understanding of work (see above), this means at least two things:

- The work we do - whatever it may be - is a calling from God. We do it in the spirit of Colossians 3:23 (NIV): 'Whatever you do, work at it with all your heart, as working for the Lord, not for men'.

- We must determine what kind of work it is when we confess that the congregation is the working people of the Lord - meaning that it is definitely not 'our' work to take over the work of God's people.

It may be one of the main tasks of denominations to review their understanding of the role or work of the congregation

1.God in Christ calls upon us, God summons us in Christ to serve Him even in our daily business' (freely translated by M. Nel). 
within God's economy. It is a non-negotiable task to radically think through the consequences of missional theology and consequently missional congregations. A new kind of 'work' is on our hands. This has critical implications for training too (cf. Nel 2005:459-506). To explore this is outside the scope of this article. We are, however, convinced that such training will be and should be steeped in an understanding of the congregation as a congregation in mission. Within a missional hermeneutic, we train pastors not to take over the ministry of the people but to equip the people for the ministry that only they can fulfil. Van Gelder (2007) introduces the:

important hermeneutical turn congregations need to keep in mind in the discerning process ... Hermeneutical turn is a multiperspectival, interpretative communal engagement in which each discerning congregant is situated within his or her own formative history and where a tapestry of conclusions may be reached as a result of that. This discernment process seeks to encourage congregations to discover what God is up to in the surrounding congregation's neighborhood. The congregation's mission is organized around the discerned reality for what the triune God is doing in the world. (97ff.; also cf. Hahn 2012: 153-154)

Within the perspective of God's people seeking the kingdom of God (cf. Matt 6:33), this 'neighborhood' Van Gelder writes about is then wherever God's people live, work and play.

We are convinced that taking this into account when we discern what is 'special' about the calling to full-time congregational ministry is healthy 'secularisation'. It is indeed very special to be entrusted with the 'job' or profession to equip the seekers of the kingdom, wherever they are and in (and through) whatever they do (cf. Matt 6:33). It is, however, also 'just' a work, a job, a profession.

A lot has been written in favour of and even questioning this approach (for a more in-depth discussion, cf. Nel 2004:584-618). Schner (1993:2) explains the three meanings in which the concept 'professional' is being used. Firstly, there is the connection with what one may call a profession (Beruf), a job. Secondly, there is the meaning of the difference between being a 'professional' and an 'amateur'. Thirdly, we need to note the general meaning, 'where professional means "qualified" or "competent" or even simply "welldone"'. In a previous article, Nel (2002:153) had used the concept far more with the last meaning. In this sense, we need to 'secularise' the concept of the calling to full-time congregational ministry: 'We need to get the calling to be a pastor on the level where we expect qualified competency in the same way we expect any other Christian to be qualified and competent in their professions'. The words of the Lord, 'Well done, good and faithful servant' (Matt 25:21), apply to 'us' too. In the words of Schner (1993:xiii), we need to rediscover that to be a pastor means 'to be professional, practical, and devoted'. The focus of this article is not to explore this professional character of this 'calling' any further and in detail. Others (cf. Carroll 1985, 1986) have already done so in depth earlier (also cf. Schwanz 2008).
We are convinced, however, that we will not get the 'special' nature of this calling back in full until we acknowledge and respect the similarities with all other callings to whatever profession Christians (and for that matter all human beings) are involved in. Our calling is not that different. Our specific job - to prepare all God's people for ministry - makes what has been entrusted to us very special. It is in this sense a very high office to be involved in.

In Article 9, which deals with the understanding of the calling of the pastor in the Church Order of the Dutch Reformed Church, a rather dramatic turn was approved in 2007 (http: / / www.ngkerkas.co.za). Even though this is a small step, it is a positive one towards accommodating the missional identity and character of this church. Within the aforementioned argumentation, the main shift was to provide for both what pastors need to do (e.g. preaching and administering the sacraments), on the one hand, and a collective responsibility with the rest of the body to be involved in the comprehensive ministry of the people of God, on the other. The shift is in the direction of being responsible for preparing the body for ministry. The article also calls for involvement in the denomination and the world as such.

\section{Conclusions}

We hope the work and life of Graham Duncan as a historian, deeply interested and involved in the life and work of the church, will continue to inspire his former students and colleagues to rethink, even in a radical way, the calling and training of the 'called ones' for full-time ministry. We may even have to turn down those who claim to be called but shy back from being trained in a professional way - trained to do a job for which they are qualified and in which they will be competent. It is probably unnecessary to repeat that, in the light of what has been argued above, this means that such called ones have to:

- be serious about the missional identity of the congregation - they are God's representatives wherever they are, in whatever they do

- realise that the involvement of God's people is one of discerning where God is at work and then, in the Spirit of the Christ, participating in what he is already doing in his world

- take on a different role of preparing God's people for that discernment and that ministerial involvement and participation

- show a willingness and commitment to be prepared, and continue to stay prepared, to in no way take over what only God's people can do but to take a back seat, viewing ministry in all its dimensions to prepare the people of God.

\section{Acknowledgements Competing interests}

The authors declare that they have no financial or personal relationships that may have inappropriately influenced them in writing this article. 


\section{Authors' contributions}

M.N. (University of Pretoria) and E.S. (Dutch Reformed Church) contributed equally to the writing of this article.

\section{References}

Alphonso, H., Discovering your personal vocation. The search for meaning through the spiritual exercises [Kindle Version], Paulist, New York.

Barth, K., 1961, The doctrine of creation: Church Dogmatics volume III/4, transl. A.T. Mackay, T.H.L. Parker, H. Knight, H.A. Kennedy \& J. Marks, Clark, Edinburgh.

Bosch, D.J., 1991, Transforming mission, Mary Knoll, New York.

Calvijn, J., 1972, Uitlegging op den Eersten en Tweeden Zendbrief van Paulus aan de Corinthiërs, transl. J. Donner, De Groot, Goudriaan.

Calvin, J., 1960a, Institutes of the Christian religion (1), transl. F.L. Battles, Westminster, Philadelphia.

Calvin, J., 1960b, Institutes of the Christian religion (2), transl. F.L. Battles, Westminster, Philadelphia.

Carroll, J., 1985, 'The professional model of ministry: Is it worth saving?', Theological Education 21(2), 7-48.

Carroll, J., 1986, Ministry as reflective practice. A new look at the professional model, Alban Institute, Washington, DC.

Conyers, A.J., 2004, The meaning of vocation, viewed 10 August 2015 from http:// www.baylor.edu/ifl/christianreflection/VocationarticleConyers.pdf

Dawson, J., 2005, 'A history of vocation: Tracing a keyword of work, meaning and moral purpose', Adult Education Quarterly 55(3), 220-231. http://dx.doi. org/10.1177/0741713605274606

Dekker, G., 1996, Van roeping naar baan. Arbeid in godsdienstig perspectief, Ten Have, Baarn.

Fowler, J.W., 1987, Faith development and pastoral care, Fortress, Philadelphia.

Freeman, C., 2009, A new history of early Christianity, Yale University Press, New Haven.

Froelich, K., 1999, 'Luther on vocation', Lutheran Quarterly 13(2), 195-207.

Gerkin, C.V., 1991, Prophetic pastoral practice. A Christian vision of life together, Abingdon, Nashville.

Gibbs, E., 2005, LeadershipNext, Intervarsity, Downers Grove.

Gibbs, E. \& Coffey, I., 2001, ChurchNext. Quantum changes in Christian Ministry Intervarsity, Downers Grove.

Hahn, D.C., 2012, 'Congregational discerning as divine action in conversation', in D.J. Zscheile (ed.), Cultivating sent communities. Missional spiritual formation, $\mathrm{pp}$. 145-165, Eerdmans, Grand Rapids.

Hahnenberg, E.P., 2010, Awakening vocation. A theology of Christian call [Kindle Edition], Liturgical, Collegeville.
Hardy, L., 1990, The fabric of this world: Inquiries into calling, career choice, and the design of human work [Kindle Edition], Eerdmans, Grand Rapids.

Hays, R.B., 2011, First Corinthians: Interpretation - A bible commentary for teaching and preaching [Kindle Edition], WJK, Louisville.

Holl, K., 1958, 'History of the word "vocation" (Beruf)', transl. H.F. Peacock, Review \& Expositor 55(2), 126-154.

Kolden, M., 1983, 'Luther on vocation', Word and World 3(4), 382-390.

Kuzmič, R., 2005, 'Beruf and Berufung in Karl Barth's Church Dogmatics: Toward a subversive klesiology', International Journal of Systematic Theology 7(3), 262-278.

McCollough, T.E., 1961, 'The theology of Christian vocation', Religious Education 56(1), 26-30.

Nederduitse Gereformeerde Kerk, 2013, Kerkorde, viewed from http://www.ngkerkas.co.za

Nel, M., 2002, 'Predikante opleiding. Roeping, keuring en legitimering', Verbum et Ecclesia 23(1), 151-167.

Nel, M., 2004, 'Publieke Pastorale Leiers 1: Roeping, Werwing, Keuring, Opleiding, Ordening', Verbum et Ecclesia 25(2), 584-618.

Nel, M., 2005, 'Publieke Pastorale Leiers 2: Roeping, Werwing, Keuring, Opleiding, Ordening', Verbum et Ecclesia 26(2), 459-506.

$\mathrm{Nel}, \mathrm{M} ., 2015$, Identity driven churches. Who are we and where are we going?, Biblecor, Wellington.

Palmer, P.J., 2000, Let your life speak: Listening for the voice of vocation [Kindle Version], Jossey-Bass, San Francisco.

Placher, W.C. (ed.), 2005, Callings: Twenty centuries of Christian wisdom on vocation [Kindle Edition], Eerdmans, Grand Rapids.

Schaller, L., 1994, Innovations in ministry, Abingdon, Nashville.

Schner, G.P., 1993, Education for ministry. Reform and renewal in theological education, Sheed \& Ward, Kansas City.

Schwanz, J., 2008, Blessed connections. Relationships that sustain vital ministry, Rowman \& Littlefield/Alban Books, Lanham.

Smit, D.J., 2002, 'Oor roeping en arbeid in Protestanse etiek', Verbum et Ecclesia 23(2), 481-501.

Thrall, M., 1976, 'Christian vocation today', Theology 79(668), 84-89.

Van Gelder, C., 2007, The ministry of the missional church. A community led by the spirit, Baker Books, Grand Rapids.

Van Gelder, C. \& Zscheile, D.J., 2011, The missional church in perspective: Mapping trends and shaping the conversation, Baker Books, Grand Rapids.

Weber, M., 1920, 'Die Protestantische Ethik und der Geist des Kapitalismus', in Gesammelte Aufsätze zur Religionssoziologie, vol. 1, pp. 17-206, Tübingen.

Weber, M., 1991, 'Der Laie in der Kirche: Grenze und Möglichkeiten', Theologia Practica 26(2), 118-122.

Williams, R., 2014, Open to judgement: Sermons and addresses [Kindle Version], Darton, Longman and Todd, London.

Wuthnow, R., 1992, God and mammon in America, Oxford University Press, New York. Wurth 1951:257-258. 